\title{
A Case Study of Soil Moisture and Infiltration after an Urban Fire
}

\author{
Quinn Alkin and Alicia M. Kinoshita * (10) \\ Department of Civil, Construction, and Environmental Engineering, San Diego State University, \\ 5500 Campanile Dr., San Diego, CA 92182, USA; quinnpwalker@gmail.com \\ * Correspondence: akinoshita@sdsu.edu
}

Received: 5 May 2020; Accepted: 5 June 2020; Published: 7 June 2020

\begin{abstract}
There is an increased risk of future fire disturbances due to climate change and anthropogenic activity. These disturbances can impact soil moisture content and infiltration, which are important antecedent conditions for predicting rainfall-runoff processes in semi-arid regions. Yet these conditions are not well documented. This case study provides critical field measurements and information, which are needed to improve our understanding of mechanisms such as precipitation and temperature that lead to the variability of soil properties and processes in urban and burned landscapes. In June 2018, a fire burned a portion of the riparian zone in Alvarado Creek, an urban tributary of the San Diego River in California, United States. This fire provided an opportunity to observe soil moisture content and infiltration for one year after the fire. Three transects (one burned and two unburned) were monitored periodically to evaluate the complex spatial and temporal dynamics of soil moisture and infiltration patterns. Average dry season soil moisture content was less than five percent volume water content (\%VWC) for all transects, and the burned transect exhibited the lowest \%VWC during the wet season. Infiltration rates displayed a high degree of spatial and temporal variability. However, the location with the highest burn severity had the lowest average infiltration rate. The observed differences between the burned and unburned transects indicate that the fire altered hydrologic processes of the landscape and reduced the ability of the soil to retain water during the wet season. This research provides the first high-resolution soil moisture and infiltration field analysis of an urban fire-disturbed stream in southern California and a method to characterize post-fire hydrologic conditions for rainfall-runoff processes.
\end{abstract}

Keywords: urban fire; soil moisture; infiltration; soil processes

\section{Introduction}

Climate variation and anthropogenic activity are increasing the risk of future fire disturbances in wildland and urban areas in California, United States [1-3]. Studies have observed that fires in California have increased in size and severity throughout the last several decades since the 1980s $[4,5]$. The two largest fires in California's recorded history were the 2018 Mendocino Complex and 2017 Thomas Fire that burned $1858 \mathrm{~km}^{2}$ and $1141 \mathrm{~km}^{2}$ [6] and the most destructive wildfires were the 2018 Camp Fire and 2017 Tubbs Fire that damaged 18,804 structures and 5636 structures [7]. These changes in wildfire regimes driven by climate change and anthropogenic activity are likely to impact ecosystem services in California, including hydrologic properties that can alter rainfall-runoff processes [8-10]. Since 2002, the number of small urban fires (under $5 \mathrm{~km}^{2}$ ) has increased in southern California [11]. Fire-disturbed catchments in semi-arid southern California often drain to water bodies that support sensitive riparian or estuarine resources and are at an elevated risk for post-fire degraded water quality [12]. The risk of fire and spread can be enhanced by dry fuel such as non-native vegetation filling the interspaces between native vegetation in southern California $[13,14]$. 
Heavily populated areas can also contribute to altered rainfall-runoff processes, increase flood risk, and undermine public safety and ecosystem health [15]. Studies have focused on the specific hydrologic effects of wildfires [16-18], wildland-urban interface fires [12,19,20], and urbanization of landscapes $[3,15,21]$, but the hydrologic impacts of fires in urban areas of southern California are less understood. Infiltration and soil moisture are important hydrologic variables that influence rainfall-runoff relationships [22,23]. Characterizing these parameters is crucial for developing accurate post-fire rainfall-runoff models [24,25]. Studies have found that the integration of in situ soil moisture observations into rainfall-runoff models significantly improve the prediction of runoff volume and timing $[25,26]$. However, these soil water processes exhibit high spatial (location dependent) and temporal (i.e., seasonal) variability and require frequent measurement [27-34]. Regular monitoring of catchments is challenging, yet essential for representing varying conditions for different landscapes. Some studies have incorporated the use of satellite images to acquire soil moisture information [25,35-37], but are often unreliable at smaller scales and only provide relative patterns. Further, datasets of field measurements in urban areas that have been burned in southern California remain unavailable. Therefore, field investigations that increase the number and diversity of observations available for post-fire rainfall-runoff models are necessary to advance hydrologic predictions in urban catchments after disturbance [38,39].

The highest priority for future post-wildfire runoff and erosion research is to understand the relations between burn severity and soil properties including soil water content that affect meso-scale rainfall, and soil hydraulic properties like infiltration [40]. The possible impact of fire on soil moisture and infiltration varies from negligible to very severe depending on factors such as the natural variability between study sites, soil type, vegetation type, and the scale of measurement [41-45]. Laboratory studies have characterized the possible impacts of fire to soil moisture and infiltration [17,46]. However, under natural conditions, high-frequency measurements are needed to capture variability. The need for field hydrological observations in small catchments to contribute high-density and frequent measurements has also been recognized by many studies [47]. Field studies provide invaluable observations and data for understanding water demand, rapid changes in land uses, and projected climate change [48,49]. This case study presents critical post-fire soil moisture and infiltration field measurements and observations with potential application to other areas of southern California.

The objectives of this study were to (1) characterize hydrologic processes by evaluating spatial and temporal post-fire soil moisture and infiltration patterns and dynamics using direct in situ measurements under various climate and vegetative conditions and (2) develop an empirical multi-variable regression model that represents post-fire soil moisture conditions in a semi-arid climate.

\section{Materials and Methods}

\subsection{Study Area}

Alvarado Creek is an urbanized and perennial stream channel that is a tributary of the San Diego River in California, United States (Figure 1a), and is approximately 15 kilometers $(\mathrm{km})$ from the Pacific Ocean. Alvarado Creek conveys water to the San Diego River through naturalized and concrete channels and culverts for both dry weather and storm event flows. The stream channel mostly runs parallel to the heavily trafficked Interstate 8 . The creek is approximately $10 \mathrm{~km}$ in length and vegetation consists mostly of chaparral and mixed native (Salix lasiolepis, Artemisia californica, and Platanus racemosa, commonly known as willow trees, sagebrush and sycamore trees) and non-native plants (Arundo donax and Washingtonia filifera, commonly known as giant reeds and palm trees). The palm trees and giant reeds are typically overgrown and crowd the riparian zone of Alvarado Creek and other waterways in San Diego. In early 2016, W. filifera, A. donax, and large quantities of trash and debris were removed from a section of Alvarado Creek with the goal to improve creek health, reduce flooding in the surrounding area, and encourage the regrowth of native vegetation. 


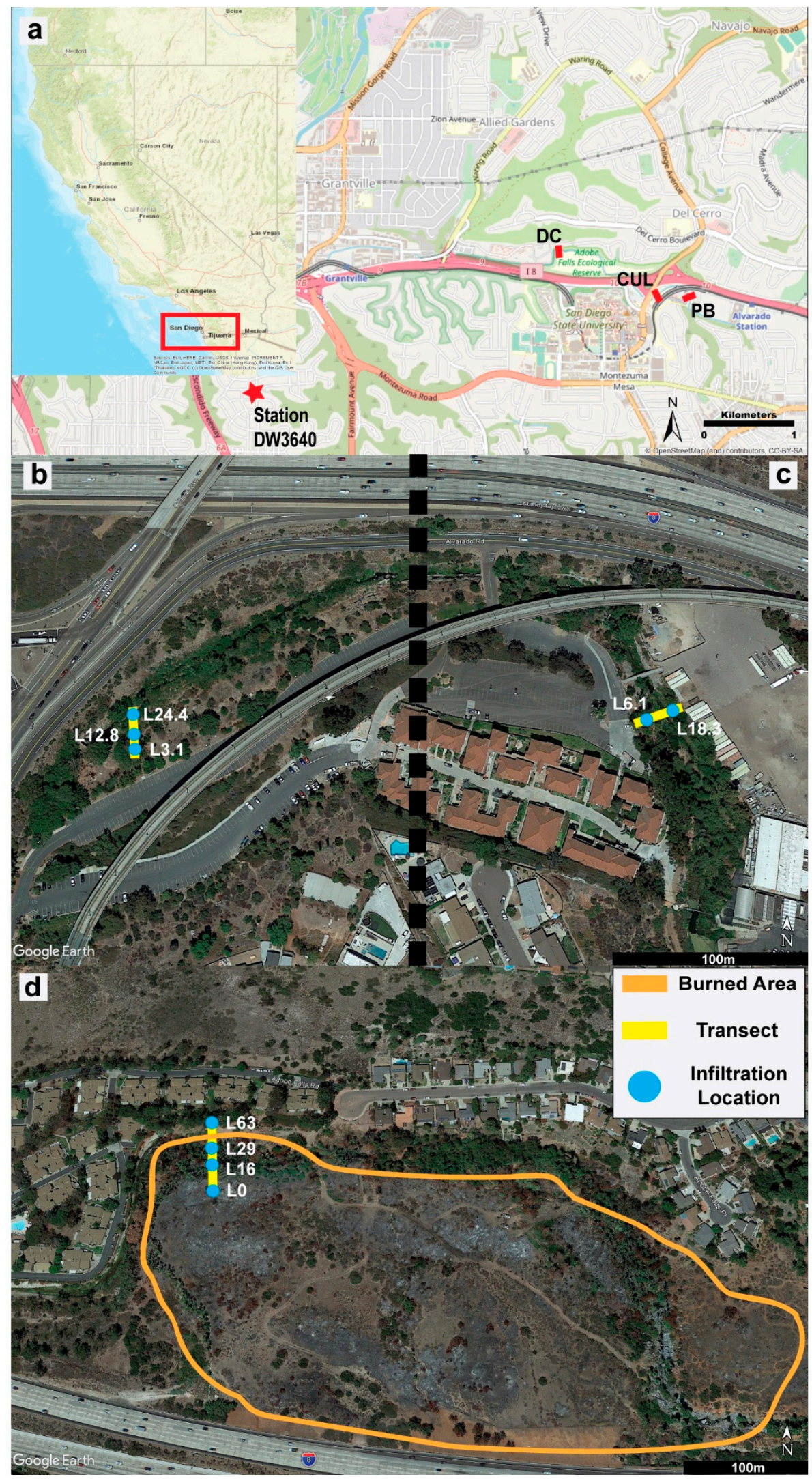

Figure 1. Location of transects at Alvarado Creek in San Diego, California, and the Citizen Weather Program Station DW3640 (a). Aerial overviews of the unburned culvert (CUL, b), unburned pedestrian bridge $(\mathrm{PB}, \mathrm{c})$, and Del Cerro (DC, d) transects. The infiltration, soil moisture, and soil sample locations are noted, and the Del Cerro fire perimeter is delineated in orange. 
The watershed area is $36.25 \mathrm{~km}^{2}$, and generally consists of developed land classifications including residential, commercial, industrial, civic, and institutional. The climatology is characterized as semi-arid Mediterranean with warm, dry summers and cool, mild winters, where 85 percent of precipitation falls between November and March [50]. Alvarado Creek responds quickly during precipitation events with large streamflows that recede rapidly thereafter. The highest temperatures are generally recorded in September and October and are usually accompanied with a drop in relative humidity of 10 to 20 percent. Warm and dry foehn winds (Santa Ana winds) typically blow from east or northeast into San Diego and greatly increase the risk of fire from June through October [50].

On 3 June 2018, a $0.15 \mathrm{~km}^{2}$ brush fire (Del Cerro Fire) burned an unrestored downstream portion of the riparian zone of Alvarado Creek, Del Cerro (DC). The Del Cerro Fire source of ignition was human and largely fueled by non-native A. donax and $W$. filifera. The fire forced the evacuations of approximately 80 homes and caused California Highway Patrol to close the Interstate 8 to all traffic. The fire also removed native vegetation and greatly enhanced the conditions for giant reeds to dominate the recovering landscape [51]. The first $A$. donax growth was observed one week after the fire and considerable non-native vegetation regrowth was observed throughout the first post-fire wet season.

Three transects (Figure $1 \mathrm{~b}-\mathrm{d}$ ) were selected to generally represent unburned (two transects) and burned (one transect) conditions in natural sections of the creek. Transects were also safely accessible, which facilitated monthly monitoring for the first year after the fire. The upstream unburned areas, pedestrian bridge (PB) and culvert (CUL), were characterized by steep hillslopes, narrow channel cross-sections, and sand and fine sandy loam soil types [52]. PB is at the beginning of the natural section of Alvarado Creek and is approximately $0.4 \mathrm{~km}$ upstream of CUL. These transects were first installed in late 2016 after vegetation restoration and provided baseline or undisturbed conditions for this study. The downstream burned area, Del Cerro (DC_B), was in a larger canyon with a wider cross-section (Figure 1d), contained large berms of $A$. donax., and was characterized by cobbly loam and riverwash material [52]. The location of the DC transect is approximately $1.2 \mathrm{~km}$ downstream of CUL before the stream transitions from a natural to concrete bottom. The established transect in DC also included an unburned section (DC_UB) used for comparison to the burned portion of the same transect. DC_UB was characterized by hard and compacted soil mixed with riverwash material.

Sewer infrastructure [53] in the area includes an underground 0.69 meter $(\mathrm{m})$ diameter sewer main made of vitrified clay, which intersects the CUL transect at location $4 \mathrm{~m}$ (Figure 2b). A concrete encasement surrounds the sewer main section at the CUL. A $0.91 \mathrm{~m}$ diameter sewer main made of polyvinylchloride (PVC) intersects the DC transect around location $50 \mathrm{~m}$ (Figure 2c). The sewer main section at the DC transect is covered with earth fill. 

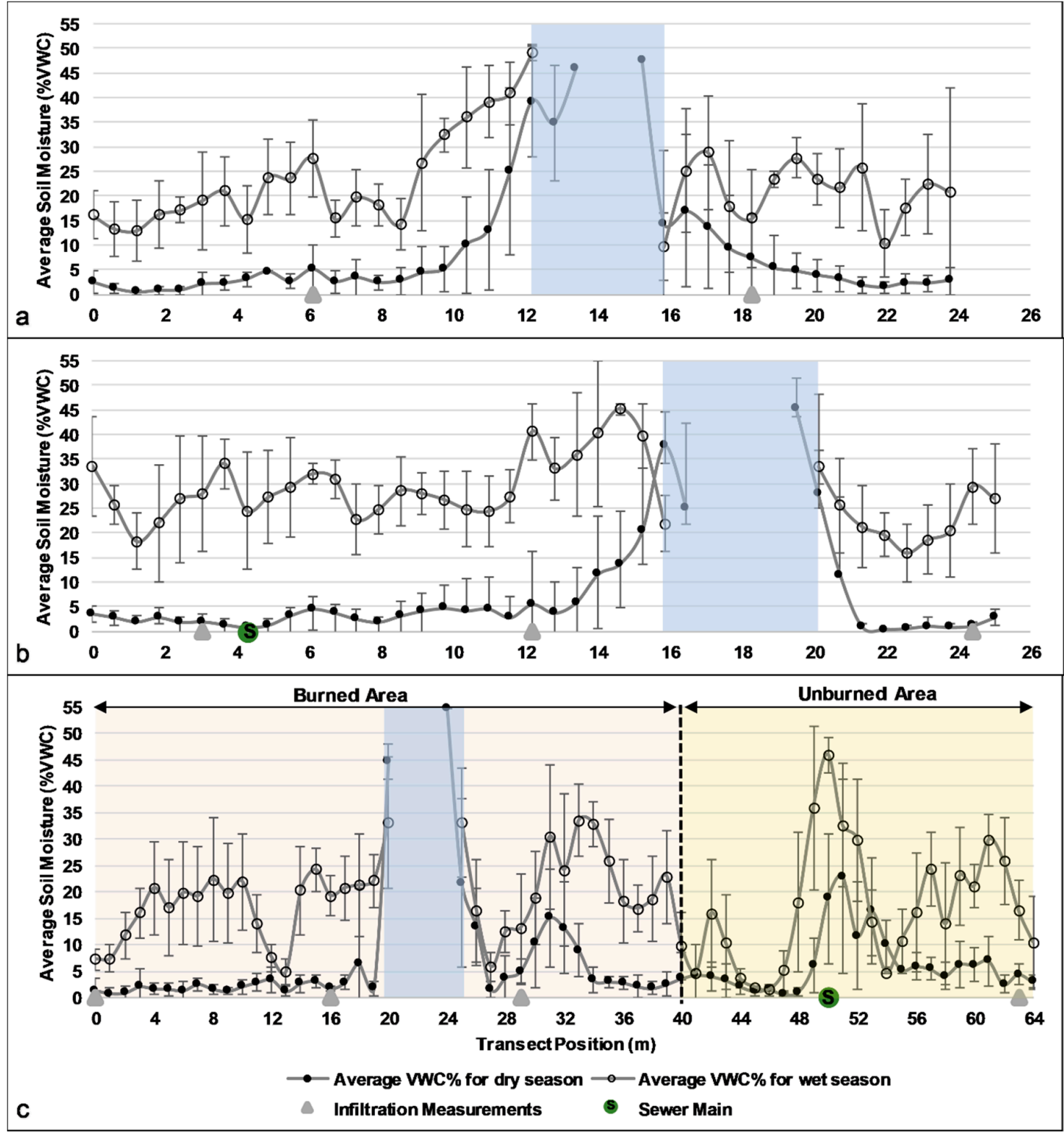

Figure 2. Average soil moisture (\%VWC) and standard deviation for each transect position $(\mathrm{m})$ along the unburned pedestrian bridge (PB) transect (a), the unburned culvert (CUL) transect (b), and Del Cerro (DC) transect from 30 June 2018 to 21 September 2019 (c). All transects start from the downstream-facing left bank and end at the downstream-facing right bank. The gray line with black closed circles represents average soil moisture content during the dry season. The gray line with black open circles represents average soil moisture content during the wet season. The vertical grey shading represents the location of the creek, where the width varies between the dry and wet season. The locations of infiltration measurements (solid gray triangle) and approximate location of the sewer main (S) are denoted. The burned and unburned sections of the transect are highlighted for Del Cerro.

\subsection{Field Observations and Meterological Data}

Soil moisture was measured for 21 dates at PB, 19 at CUL, and 14 at DC between May 2018 and September 2019. The measurements were collected every $0.61 \mathrm{~m}$ at the PB and CUL transects (unburned), and every $1 \mathrm{~m}$ at the DC (burned (DC_B) and unburned (DC_UB)) with a $12 \mathrm{~cm}$ or $15 \mathrm{~cm}$ C659 probe attached to a Campbell Scientific Hydrosense II. While, relative soil moisture can be estimated using modeling or remote sensing [33]; our method directly measured soil moisture and provided a high-resolution, accurate, and reliable ground-based range of values and statistical averages. 
The measured percent volume water content (\%VWC) ranges from $0 \%$ to $50 \%$ with an accuracy of $\pm 3 \%$, and a precision of less than $0.5 \%$ [54]. Soil moisture was not measured in sediment at the water surface or in the stream; these locations were assumed to be fully saturated with water. The wet and dry season average at each transect position were estimated. The dry season measurements included 26 May 2018 to 20 October 2018 and 1 September 2019 and 21 September 2019. The wet season measurements included 2 December 2018 to 16 March 2019.

Infiltration was measured on the same dates as the soil moisture measurements from May 2018 to September 2019 using a mini disk infiltrometer [55]. Tension infiltrometers such as the mini disk infiltrometer have been used in other studies to determine the spatial and temporal variability of in situ hydraulic conductivity and infiltration rates [32,56]. The amount of water infiltrated was divided by the time between measurements to obtain a rate in centimeters per second $(\mathrm{cm} / \mathrm{s})$. The calculated infiltration rate was then averaged for all time steps and converted to centimeters per hour $(\mathrm{cm} / \mathrm{h})$ for each location on all dates that measurements were performed. Table 1 summarizes the infiltration measurement locations. Multiple locations were chosen for each transect to represent inherent spatial differences across the various landscapes, and at least one location was on the left and right banks of the stream channel for PB, CUL, and DC.

Table 1. Description of infiltration locations for the unburned pedestrian bridge (PB), unburned culvert (CUL), burned Del Cerro (DC), and unburned (DC_UB) sites. The names are defined as the sampling position along the transect, which is located a specific distance in meters from the start of the transect.

\begin{tabular}{ccc}
\hline Transect & Location Name & Description \\
\hline PB & L6.1 & Bottom of the left bank upland section under a tree near the streambed, \\
located at $6.1 \mathrm{~m}$
\end{tabular}

Daily temperature and precipitation data were gathered and compiled from MesoWest [57]. Station DW3640 is part of the Citizen Weather Program in San Diego, California, which is near Alvarado Creek and has an elevation of $114 \mathrm{~m}$ (Figure 1). Station DW3640 was assumed representative of the climate of Alvarado Creek due to the proximity (less than $2 \mathrm{~km}$ away) and minimal elevation difference.

\subsection{Statistical Analysis}

The minimum, maximum, median, average, and standard deviation were estimated for soil moisture and infiltration rates for each site (PB, CUL, DC_B, DC_UB) and burned and unburned conditions. P-values were derived by conducting unpaired t-tests with a $95 \%$ confidence interval (CI) to test the null hypothesis that there was no observed or significant difference between the means of two dataset populations. If the two-tailed p-values were less than 0.05 , the null hypothesis was rejected. Single linear regression analysis was performed to obtain $\mathrm{R}^{2}$ values based on accumulation of 
precipitation for observations from water year 2019 (1 October 2018 to 30 September 2019). A model to predict soil moisture content based on temperature and accumulation of precipitation was created using an empirical multi-variable regression method. All statistical and regression analyses were performed using the Data Analysis tool provided by Microsoft Excel, Version 1908.

\section{Results}

\subsection{Burned and Unburned Soil Moisture}

Soil moisture was analyzed during the dry and wet season at each transect, revealing spatial and temporal variability along each transect (Figure 2). Many soil moisture content values were lower in burned locations when compared to unburned areas due to changes in landscape and soil characteristics. Four different points along the burned transect, DC_B, were less than $10 \%$ VWC during the wet season, and most of the measured transect positions were below $25 \% \mathrm{VWC}$ along the burned left side of the transect (Figure 2c). Many of the \%VWC values at the DC_UB measurement locations resembled the values obtained at the unburned PB and CUL transects and were above $15 \% \mathrm{VWC}$. The lowest average \%VWC for the wet season was DC_B $(19.3 \pm 11.6 \% \mathrm{VWC}, 95 \%$ CI, 16.7-21.8) and DC_UB $(17.0 \pm 7.6,95 \% \mathrm{CI}, 12.2-21.8)$, when compared to the wet season populations for PB (22.6 $\pm 8.7 \%$ VWC, 95\% CI, 19.5-25.6) and CUL ( $28.0 \pm 6.7 \%$ VWC, 95\% CI, 25.0-30.3). The highest average \%VWC of any transect position during the wet season, not within $4 \mathrm{~m}$ of the stream, was approximately $45.2 \%$ VWC nearby the underground sewer main at transect position $50 \mathrm{~m}$ of DC_UB.

The dry season average volume water content percent at each measurement was less than approximately $5 \%$ VWC at PB and CUL for the entire transects. However, average \%VWC began to increase exponentially above $5 \% \mathrm{VWC}$ within $4 \mathrm{~m}$ of approaching either bank of the stream (Figure 2). The average \%VWC at PB was consistently higher than any other transect during the dry season for almost all dates measured (Figure 3). In Del Cerro, DC_B, the average \%VWC during the dry season was less than $5 \%$ VWC at most of the locations along the burned transect. However, in Del Cerro, the highest average soil moisture content was approximately $23 \% \mathrm{VWC}$ at transect position $51 \mathrm{~m}$, which coincides with the sewer main.

Precipitation greatly affects soil moisture content in semi-arid landscapes [58,59], and there was evidence $(p<0.05)$ that multiple precipitation events increased the soil moisture during the wet season. High-frequency measurements showed that precipitation increased soil moisture values in the stream channel for both burned and unburned areas. Soil moisture consistently increased at each date during the wet season and peaked for all transects on March 16, 2020. CUL exhibited the highest average and median \%VWC for every date during the wet season (Figure 3). The wet season average \%VWC increased significantly compared to the dry season at every point along PB and CUL, excluding only two points that were both within $2 \mathrm{~m}$ of the water surface of the stream (Figure 2). The average of every point in the wet season were above $10 \% \mathrm{VWC}$ at PB and above $15 \% \mathrm{VWC}$ at CUL. Most of the points that did not increase above $5 \%$ VWC during the dry season were above $20 \% \mathrm{VWC}$ at $\mathrm{PB}$ and above $25 \%$ VWC at CUL. CUL exhibited the highest average and median \%VWC for every date during the wet season (Figure 3). 


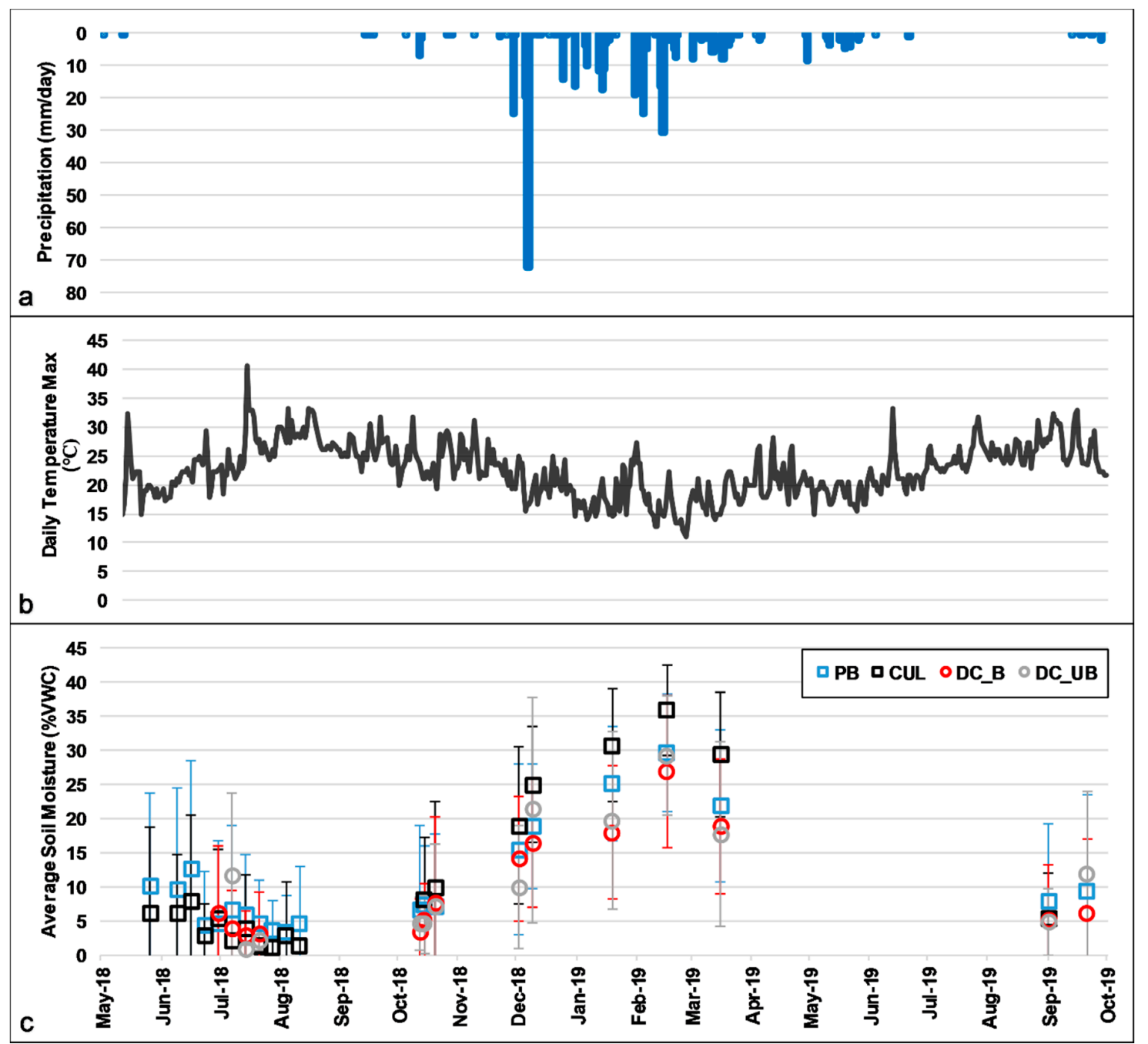

Figure 3. Daily precipitation $(\mathrm{mm})(\mathbf{a})$, daily maximum temperature $\left({ }^{\circ} \mathrm{C}\right)(\mathbf{b})$, and average soil moisture (\%VWC) for PB, CUL, DC_B, and DC_UB transects (c) at Alvarado Creek. Standard deviation bars are shown.

\subsection{A Tool to Predict Soil Moisture}

A single linear regression analysis was performed for all months during water year 2019 (Figure 4). The $\mathrm{R}^{2}$ value was $0.91\left(p=0.05 \times 10^{-1}\right)$ for average $\% \mathrm{VWC}$ and accumulation of daily precipitation per month from the beginning of the water year until the peak date of 16 March 2019. The $R^{2}$ value was $0.87\left(p=1.01 \times 10^{-42}\right)$ for average \%VWC and accumulation of daily precipitation per month from the peak date of 16 March 2019 until the end of water year 2019 (Figure 4). The multi-variable regression analysis $\left(\mathrm{R}^{2}=0.86\right.$ and $\left.p=2.09 \times 10^{-13}\right)$ resulted in the empirical equation:

$$
y=0.01 x_{1}-1.86 x_{2}+52.99
$$

where $x_{1}$ is total precipitation to date in the water year in millimeters $(\mathrm{mm}), x_{2}$ is the average monthly maximum daily temperature $\left({ }^{\circ} \mathrm{C}\right)$, and $y$ is average monthly soil moisture content (\%VWC). The $x_{1}, x_{2}$, and $y$ variables are associated with changes in the soil moisture content response variable and can be confidently used as predictors. Generally, an increase in $x_{1}$ and a decrease in $x_{2}$ will result in an increase in soil moisture content. However, an increase in $x_{2}$ with no increase or decrease in $x_{1}$ will result in decreased soil moisture content. 


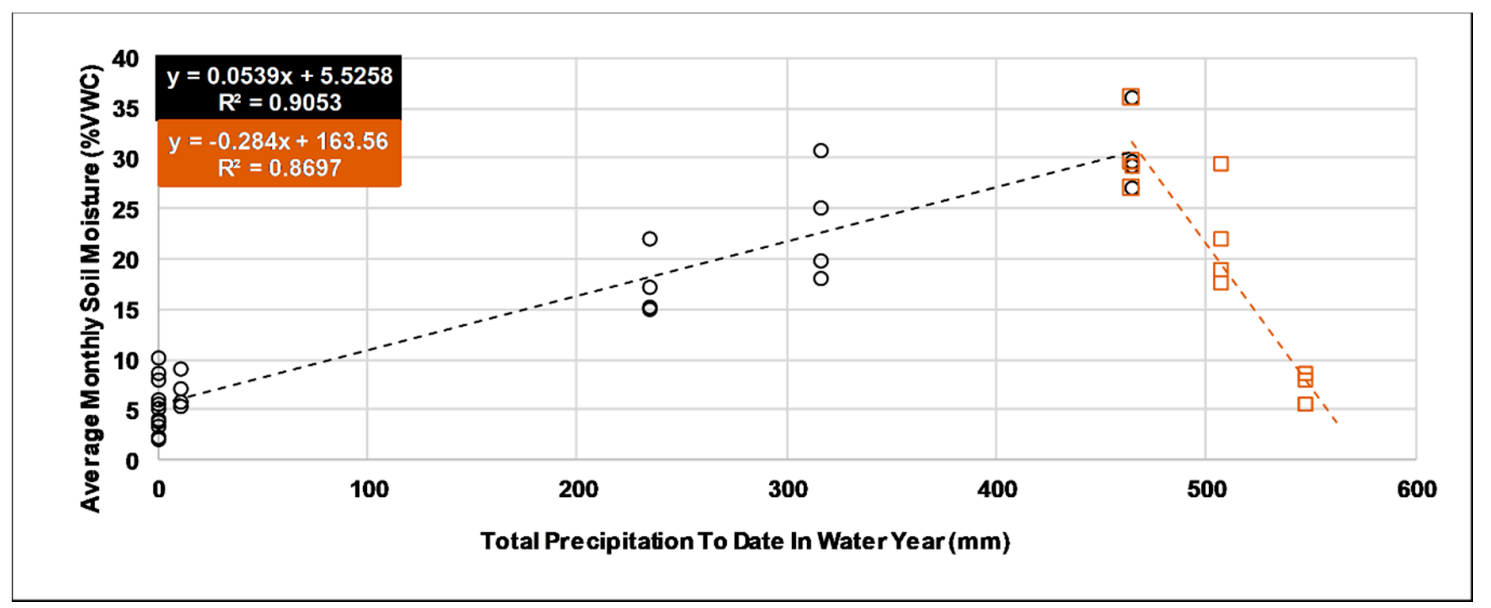

Figure 4. Linear regression analysis of all sites during water year 2019 for average soil moisture (\%VWC) and total precipitation to date $(\mathrm{mm})$. The open black circles represent measurements from $0 \mathrm{~mm}$ of precipitation until the average soil moisture peaked in March 2019 at $465 \mathrm{~mm}$ of total precipitation in water year 2019 (wet season). The brown squares represent measurements from the peak average soil moisture until the end of the water year 2019 where the total precipitation was $548 \mathrm{~mm}$ (dry season).

\subsection{Burned and Unburned Infiltration}

Infiltration rates ranged from 3 to $73 \mathrm{~cm} / \mathrm{h}$ and exhibited significant spatial and temporal variability throughout the study period (Table 2). Every date produced a wide range of infiltration rates, regardless of wet or dry season. Some measurements were recorded within one week of each other and differed by $\pm 20 \mathrm{~cm} / \mathrm{h}$ at the same location. The total average and median infiltration rate at Alvarado Creek were $26 \pm 16$ and $22 \mathrm{~cm} / \mathrm{h}$, respectively. The total dry season average was $26 \pm 16 \mathrm{~cm} / \mathrm{h}$ and the total wet season average was $29 \pm 15 \mathrm{~cm} / \mathrm{h}$. Generally, the unburned locations at the PB, CUL, and DC transects exhibited similar ranges, averages, and medians for the duration of the study. Five of the nine locations had a higher average infiltration rate in the wet season than in the dry season, three had a lower average infiltration rate (CUL L24.4, D_B L0, DC_B L29), and one was nearly the same for both (DC_B L16) (Figure 5). The lowest average wet season infiltration rate $(14 \mathrm{~cm} / \mathrm{h} \pm 6)$ was observed at the burned upland slope location (DC_B L0). The highest average wet season infiltration rates were observed at DC_B L16 and DC_B L29. There was no evidence $(p>0.05)$ that infiltration rates decreased or increased during the wet season for every location, except for the decrease at DC_B L0 $(p<0.05)$.

Table 2. Range, mean, and median infiltration rates $(\mathrm{cm} / \mathrm{h})$ for the unburned pedestrian bridge (PB), unburned culvert (CUL), burned Del Cerro (DC_B), and unburned Del Cerro (DC_UB) transect locations.

\begin{tabular}{cccc}
\hline Location & Range (cm/h) & Mean $\mathbf{( c m} / \mathbf{h})$ & Median $\mathbf{( c m} / \mathbf{h})$ \\
\hline PB L6.1 & $4-64$ & $22 \pm 17$ & 15 \\
PB L18.3 & $5-41$ & $22 \pm 10$ & 20 \\
CUL L3.1 & $3-39$ & $21 \pm 10$ & 20 \\
CUL L12.8 & $8-44$ & $26 \pm 14$ & 19 \\
CUL L24.4 & $5-58$ & $26 \pm 17$ & 21 \\
DC_B L0 & $4-42$ & $19 \pm 12$ & 15 \\
DC_B L16 & $12-46$ & $34 \pm 9$ & 34 \\
DC_B L29 & $7-73$ & $45 \pm 22$ & 49 \\
DC_UB L63 & $9-46$ & $22 \pm 9$ & 18 \\
\hline
\end{tabular}




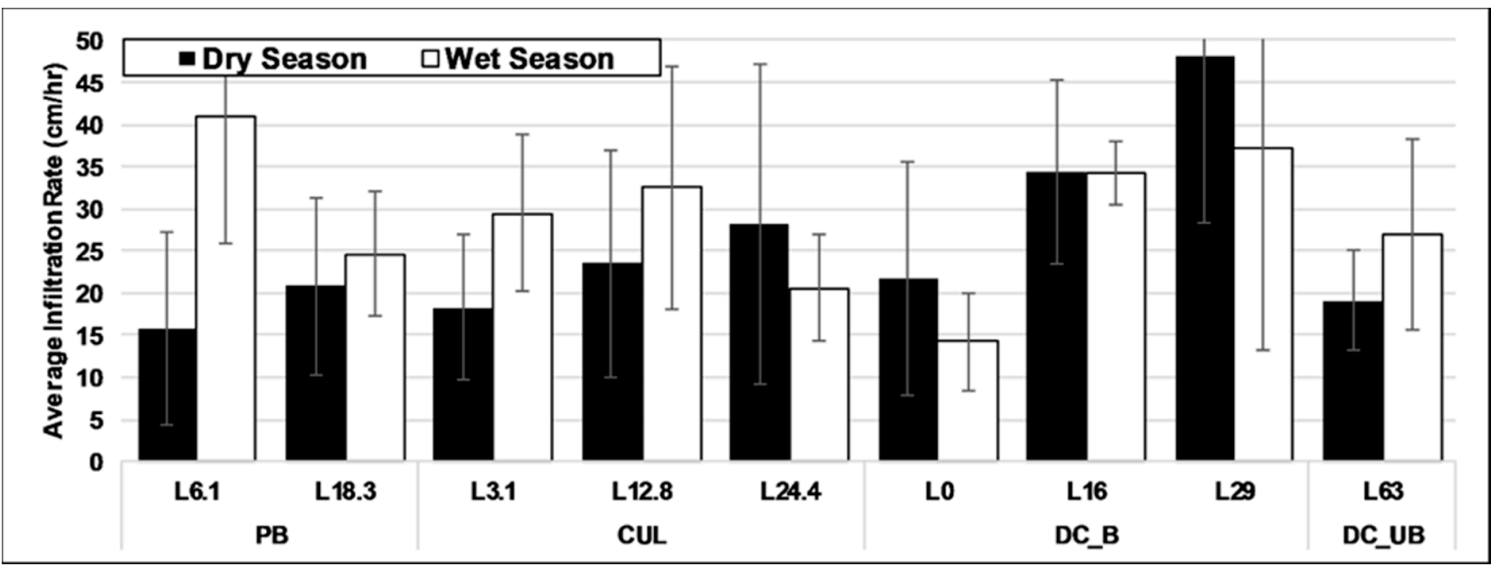

Figure 5. Wet and dry season average infiltration rates $(\mathrm{cm} / \mathrm{h})$ for all locations. Standard deviation bars are shown.

\section{Discussion}

\subsection{Soil Moisture}

Previous literature has found that the variability of soil moisture values across a landscape is larger for extreme wet and dry conditions, with less variation and similar values across an area of intermediate wetness [60-63]. In this study, we observed different distinct trends and patterns due to seasonality and fire. There were minimal differences in average soil moisture along most transect points during the dry season, suggesting that soil moisture can be monitored less during the dry season. The average \%VWC for all transects was also similar to observations for other southern California chaparral landscapes [64] and supports a threshold of approximately $10 \%$ VWC for all transects during the dry season (Figure 3). Additionally, the PB transect is characterized by dense vegetation and substantial canopy cover, thus contributing to reduced evapotranspiration and higher soil moisture at this site through the dry season. The ground surface of the Alvarado Creek channel was significantly desiccated during the dry season but appears representative of other urban areas of southern California.

This study also highlights the differences between the burned and unburned transects during the wet season. As expected, the stream width increased during the winter from approximately $2-3$ $\mathrm{m}$ during the dry season to approximately $4-5 \mathrm{~m}$ for all sites during the wet season. This variable area growth and contraction is often localized around stream networks in urban areas and during the generation of saturation excess runoff [65]. The burned area exhibited low soil moisture content during the wet season and is likely based on characteristics such as soil type, topography, canopy cover and density, local infrastructure, and proximity to the streambed [66]. The reduced soil moisture content in the burned area may also be attributed post-fire soil hydrophobicity, a waxy coating created after vegetation volatizes and resettles on the surface, which is often observed in burned watersheds [67]. Overall, this suggests a potential to increase runoff at the DC transect due to enhanced water repellency impacting the ability of burned soils to retain water during post-fire precipitation events. While data collection is limited to only three transects, this study provides the first high-resolution dataset of soil moisture content in a southern California urban stream that can be used to validate field or remote sensing techniques. This study will benefit from future research that augments our work with multiple transects in burned areas.

Korres et al. [33] estimated that soil moisture content varied less across the landscape at higher values in grassland and forests, whereas the soil moisture content varied more at higher values in our study areas. The wet season notably increased the variability between each position and each transect, indicating that higher frequency monitoring during the wet season is needed to increase the accuracy and reliability for rainfall-runoff predictions in urban areas. The observed increase in 
temporal and spatial variability is driven by precipitation and temperature during the wet season. CUL likely exhibited the highest average \%VWC for most dates during the wet season due to less vegetation density and sandy loam soil. This could increase ground penetration of rainfall and retention of water, thus resulting in an increased soil moisture content for the CUL transect. Exfiltration potentially saturated the ground near the sewer main along DC_UB, which contributed to the consistently higher dry season soil moisture at this location. This is similar to other studies, in which wastewater from sewer mains exfiltrated and contaminated ground and surface water in urban areas [68-70].

\subsection{Multi-Variable Empirical Model}

Studies have investigated the interaction of precipitation on various landscapes to predict soil moisture [71,72]. These studies produced soil moisture prediction models using various meteorological inputs such as daily precipitation, relative humidity, and temperature. Many land surface models also require soil moisture estimates as a fundamental requirement to predict runoff volume and stream flowrates during precipitation events [73]. This research builds on previous studies and introduced a multi-variable empirical regression model based on accumulation of rainfall and temperature that estimates soil moisture content throughout a water year in burned and unburned semi-arid urban areas. Although this empirical model is limited to data from one water year, it is the first to provide a method to estimate soil moisture content without relying on rainfall intensity. The results presented here suggest that a large storm event may not produce high soil moisture content early in the wet season unless preceded by consecutive precipitation events. The model also indicated that small consecutive storms can sufficiently increase the soil moisture content through the wet season for both the burned and unburned areas. While this model can be improved further with more field measurements of semi-arid stream channels during the wet season, the data from this case study can be integrated into other studies [48], for example, to validate field or remote sensing techniques. We also encourage the use of this study as a framework for future research that creates and calibrates rainfall-runoff models and evaluates other hydrologic processes in undisturbed and fire-disturbed semi-arid landscapes.

\subsection{Infiltration}

The infiltration rates observed at Alvarado Creek are within the clean gravel and sand mixture range [74] and correspond with rates reported in other urban area studies [21,75]. However, factors such as soil types, grain size, soil texture, pore geometry, vegetation cover, burn severity, slope aspect, and proximity to the stream water surface affect infiltration [76-82] and are difficult to isolate in the field. The DC_B L0 location was approximately $20 \mathrm{~m}$ from the water surface and did not experience a high amount of vegetation recovery or landscape alteration. The infiltration rate at DC_B L0 decreased and exhibited a lower value than the unburned locations during the wet season, a typical characteristic in areas disturbed by fire due to hydrophobicity and water repellency $[28,83]$. These studies similarly found that the top layer of fire-disturbed areas exhibited hydrophobic characteristics and smaller infiltration rates during the wet season. However, in this study, there was no indication of reduced infiltration near the stream in the burned area. The highest average and median infiltration rates for the study period were at DC_B L16 and DC_B L29, which are directly adjacent to the stream water's edge and were characterized by substantial amounts of large soil particles such as sand and gravel. Radinja et al. [56] observed increased water repellency during the dry season, and diminished water repellency during the wet season in an urban area. However, our results indicate that there is no clear seasonal difference between the wet and dry season for the observed infiltration rates at all of the sites studied in Alvarado Creek.

The high infiltration rates observed in Alvarado Creek may be attributed to the depths at which the measurements were taken. The current study only measured infiltration at the surface of the soil and at no other depths. The uppermost soil layer was normally desiccated during the dry season, and water could infiltrate in a radial direction as opposed to vertically through the ground. While infiltration rates typically decrease with time during precipitation events [21], our measurements were only performed 
for approximately five minutes and none were taken during precipitation events. Many of the wet season measurements were performed a week after a storm, which allowed time for the surface layer to dry, particularly in sandy areas. Research to characterize the inherent variability of post-wildfire soils is ongoing [77]. Generalizing infiltration requires a large amount of measurements to establish and extrapolate any scale larger than $1 \mathrm{~m}$. Infiltration rates can be overgeneralized for small and large waterways and require more discrete observations for local stream phenomena $[47,49]$.

\section{Conclusions}

This case study is the first to perform a high-resolution assessment of post-fire hydrologic soil moisture and infiltration conditions in an urban semi-arid southern California creek. Variability increased during the wet season between each position and transect, and the lowest average and median soil moisture content was the burned transect. Soil moisture was found to be dependent on the accumulation of rainfall as opposed to intensity. Urban infrastructure such as sewers also influenced soil moisture measurements during the study. A multi-variable regression model based on empirical data that can predict soil moisture content was presented and can be used to assist rainfall-runoff modeling efforts in southern California. The average infiltration rate of the surface layer was $26 \pm 16 \mathrm{~cm} / \mathrm{h}$ and each measurement varied significantly by date and location. The lowest observed average wet season infiltration rate $(14 \mathrm{~cm} / \mathrm{h})$ was at the burned location, and the locations near the water surface in the burned riparian zone produced the highest infiltration rates throughout the study period. Surface infiltration rates in the riparian zone of the urban creek were not significantly affected by temperature and precipitation. Location, landscape factors, bank erosion, sediment deposition, and soil type differences contributed to the complexity of spatial and temporal analyses of soil hydrologic properties. This case study contributes valuable field data that are needed for understanding the mechanisms of precipitation and temperature on the variability in fire effects on soil properties and processes. Our findings have broad implications for post-fire stormwater and flood modeling and the impacts on downstream communities and ecosystems. The characterizations presented in this study can be applied to other urbanized streams in southern California and contribute to the improvement of rainfall-runoff simulations and flood inundation predictions in other semi-arid coastal watersheds.

Author Contributions: Conceptualization, Q.A. and A.M.K.; methodology, Q.A. and A.M.K.; validation, Q.A. and A.M.K.; formal analysis, Q.A.; investigation, Q.A.; resources, A.M.K.; data curation, Q.A.; writing-original draft preparation, Q.A.; writing — review and editing, A.M.K. and Q.A; visualization, Q.A.; supervision, A.M.K.; project administration, A.M.K.; funding acquisition, A.M.K. All authors have read and agreed to the published version of the manuscript.

Funding: This material is based upon work supported by the National Science Foundation CAREER Program under grant number 1848577 and the San Diego River Conservancy under grant number SDRG-P1-18-15.

Acknowledgments: The authors would like to acknowledge and thank the numerous field volunteers at the Disturbance Hydrology Lab. We are especially thankful to Peris Salih and Evelyn Alkin for their dedication and assistance in collecting field data. The authors also thank the editors and three anonymous reviewers for their thoughtful comments.

Conflicts of Interest: The authors declare no conflict of interest. The funders had no role in the design of the study; in the collection, analyses, or interpretation of data; in the writing of the manuscript, or in the decision to publish the results.

\section{References}

1. Diffenbaugh, N.; Swain, D.L.; Touma, D. Anthropogenic warming has increased drought risk in California. Proc. Natl. Acad. Sci. USA 2015, 112, 3931-3936. [CrossRef] [PubMed]

2. Davis, R.; Yang, Z.; Yost, A.; Belongie, C.; Cohen, W. The normal fire environment-Modeling environmental suitability for large forest wildfires using past, present, and future climate normals. For. Ecol. Manag. 2017, 390, 173-186. [CrossRef] 
3. Syphard, A.D.; Keeley, J.E.; Pfaff, A.H.; Ferschweiler, K. Human presence diminishes the importance of climate in driving fire activity across the United States. Proc. Natl. Acad. Sci. USA 2017, 114, 13750-13755. [CrossRef] [PubMed]

4. Westerling, A.L.; Hidalgo, H.G.; Cayan, D.R.; Swetnam, T.W. Warming and earlier spring increase western U.S. forest wildfire activity. Science 2006, 313, 940-943. [CrossRef]

5. Miller, J.; Safford, H.; Crimmins, M.; Thode, A. Quantitative Evidence for Increasing Forest Fire Severity in the Sierra Nevada and Southern Cascade Mountains, California and Nevada, USA. Ecosystems 2009, 12, 16-32. [CrossRef]

6. California Department of Forestry \& Fire Protection. Top 20 Largest California Wildfires. Available online: https://www.fire.ca.gov/media/5510/top20_acres.pdf (accessed on 15 December 2019).

7. California Department of Forestry \& Fire Protection. Top 20 most Destructive California Wildfires. Available online: https://www.fire.ca.gov/media/5511/top20_destruction.pdf (accessed on 15 December 2019).

8. Lasanta, T.; Cerdà, A. Long-term erosional responses after fire in the Central Spanish Pyrenees. Catena 2005, 60, 81-100. [CrossRef]

9. Karl, T.R.; Meehl, G.A.; Miller, C.D.; Hassol, S.J.; Waple, A.M.; Murray, W.L. Weather and climate extremes in a changing climate. Regions of focus: North America, Hawaii, Caribbean, and US Pacific Islands. Synth. Assess. Prod. 2008, 3, 16-19.

10. Westerling, A.; Bryant, B.; Preisler, H.; Holmes, T.; Hidalgo, H.; Das, T.; Shrestha, S. Climate change and growth scenarios for California wildfire. Clim. Chang. 2011, 109, 445-463. [CrossRef]

11. California Department of Forestry \& Fire Protection. California's Forests and Rangelands: 2017 Assessment. Available online: https://frap.fire.ca.gov/media/3180/assessment2017.pdf (accessed on 4 May 2020).

12. Stein, E.D.; Brown, J.S.; Hogue, T.S.; Burke, M.P.; Kinoshita, A. Stormwater contaminant loading following southern California wildfires. Environ. Toxicol. Chem. 2012, 31, 2625-2638. [CrossRef]

13. Minnich, R.A. Chaparral Fire History in San Diego County and Adjacent Baja California: An Evaluation of Natural Fire Regimes and the Effects of Suppression Management. California Chaparral: Paradigms Reexamined. Natural History Museum of Los Angeles County, Science Series 1989. Available online: https://www.fs.fed.us/psw/publications/4403/Management.pdf (accessed on 27 January 2020).

14. Brooks, M.L. Alien Annual Grasses and Fire in the Mojave Desert. Madroño 1999, 46, 13-19.

15. White, M.D.; Greer, K.A. The effects of watershed urbanization on the stream hydrology and riparian vegetation of Los Peñasquitos Creek, California. Landsc. Urban Plan. 2006, 74, 125-138. [CrossRef]

16. Letey, J. Causes and consequences of fire-induced soil water repellency. Hydrol. Process. 2001, 15, $2867-2875$. [CrossRef]

17. Leon, F. The effect of fire on soil properties. In Proceedings-Management and Productivity of Western-Montane Forest Soils, Boise, Ada, USA, 10-12 April 1990; Harvey, A.E., Neuenschwander, L.F., Eds.; Intermountain Forest Experiment Station: Ogden, UT, USA, 1991.

18. Moody, J.A.; Martin, D.A. Initial hydrologic and geomorphic response following a wildfire in the Colorado Front Range. Earth Surf. Process. Landf. 2001, 26, 1049-1070. [CrossRef]

19. Rulli, M.C.; Rosso, R. Hydrologic response of upland catchments to wildfires. Adv. Water Resour. 2007, 30, 2072-2086. [CrossRef]

20. Burke, M.; Hogue, T.; Ferreira, M.; Mendez, C.; Navarro, B.; Lopez, S.; Jay, J. The Effect of Wildfire on Soil Mercury Concentrations in Southern California Watersheds. Water Air Soil Pollut. 2010, 212, 369-385. [CrossRef] [PubMed]

21. Yang, J.-L.; Zhang, G.-L. Water infiltration in urban soils and its effects on the quantity and quality of runoff. J. Soils Sediments 2011, 11, 751-761. [CrossRef]

22. Merz, B.; Plate, E.J.; Bloesch, G.; Sivapalan, M.; Gupta, V.; Beven, K. An analysis of the effects of spatial variability of soil and soil moisture on runoff. Water Resour. Res. 1997, 33, 2909-2922. [CrossRef]

23. Brocca, L.; Melone, F.; Moramarco, T.; Singh, V. Assimilation of Observed Soil Moisture Data in Storm Rainfall-Runoff Modeling. J. Hydrol. Eng. 2009, 14, 153-165. [CrossRef]

24. Moore, R.J.; Cole, S.J.; Bell, V.A.; Jones, D.A. Issues in flood forecasting: Ungauged basins, extreme floods and uncertainty. IAHS Publ. Ser. Proc. Rep. 2006, 305, 103-122.

25. Papathanasiou, C.; Makropoulos, C.; Mimikou, M. Hydrological modelling for flood forecasting: Calibrating the post-fire initial conditions. J. Hydrol. 2015, 529, 1838-1850. [CrossRef] 
26. Gao, H.; Birkel, C.; Hrachowitz, M.; Tetzlaff, D.; Soulsby, C.; Savenije, H.H.G. A simple topography-driven and calibration-free runoff generation module. Hydrol. Earth Syst. Sci. 2018, 1-42. [CrossRef]

27. Tayfur, G.; Zucco, G.; Brocca, L.; Moramarco, T. Coupling soil moisture and precipitation observations for predicting hourly runoff at small catchment scale. J. Hydrol. 2014, 510, 363-371. [CrossRef]

28. Kinner, D.A.; Moody, J.A. Spatial variability of steady-state infiltration into a two-layer soil system on burned hillslopes. J. Hydrol. 2010, 381, 322-332. [CrossRef]

29. Kinoshita, A.M.; Hogue, T.S. Spatial and temporal controls on post-fire hydrologic recovery in Southern California watersheds. Catena 2011, 87, 240-252. [CrossRef]

30. Hatch, C.E.; Fisher, A.T.; Ruehl, C.R.; Stemler, G. Spatial and temporal variations in streambed hydraulic conductivity quantified with time-series thermal methods. J. Hydrol. 2010, 389, 276-288. [CrossRef]

31. Rosenbaum, U.; Bogena, H.R.; Herbst, M.; Huisman, J.A.; Peterson, T.J.; Weuthen, A.; Western, A.W.; Vereecken, H. Seasonal and event dynamics of spatial soil moisture patterns at the small catchment scale. Water Resour. Res. 2012, 48. [CrossRef]

32. Zeng, C.; Wang, Q.; Zhang, F.; Zhang, J. Temporal changes in soil hydraulic conductivity with different soil types and irrigation methods. Geoderma 2013, 193, 290-299. [CrossRef]

33. Korres, W.; Reichenau, T.G.; Fiener, P.; Koyama, C.N.; Bogena, H.R.; Cornelissen, T.; Baatz, R.; Herbst, M.; Diekkrüger, B.; Vereecken, H.; et al. Spatio-temporal soil moisture patterns-A meta-analysis using plot to catchment scale data. J. Hydrol. 2015, 520, 326-341. [CrossRef]

34. Rienzner, M.; Gandolfi, C. Investigation of spatial and temporal variability of saturated soil hydraulic conductivity at the field-scale. Soil Tillage Res. 2014, 135, 28-40. [CrossRef]

35. Brocca, L.; Liersch, S.; Melone, F.; Moramarco, T.; Volk, M. Application of a model-based rainfall-runoff database as efficient tool for flood risk management. Hydrol. Earth Syst. Sci. 2013, 17, 3159-3169. [CrossRef]

36. Tramblay, Y.; Bouaicha, R.; Brocca, L.; Dorigo, W.; Bouvier, C.; Camici, S.; Servat, E. Estimation of antecedent wetness conditions for flood modelling in northern Morocco. Hydrol. Earth Syst. Sci. 2012, 16, 4375-4386. [CrossRef]

37. Dabrowska-Zielinska, K.; Budzynska, M.; Kowalik, W.; Turlej, K. Soil moisture and evapotranspiration of wetlands vegetation habitats retrieved from satellite images. Hydrol. Earth Syst. Sci. 2010, 7, 5929-5955. [CrossRef]

38. Moody, J.A.; Ebel, B.A.; Nyman, P.; Martin, D.A.; Stoof, C.; McKinley, R. Relations between soil hydraulic properties and burn severity. Int. J. Wildland Fire 2016, 25, 279-293. [CrossRef]

39. Wieting, C.; Ebel, B.A.; Singha, K. Quantifying the effects of wildfire on changes in soil properties by surface burning of soils from the Boulder Creek Critical Zone Observatory. J. Hydrol. Reg. Stud. 2017, 13, 43-57. [CrossRef]

40. Moody, J.A.; Shakesby, R.A.; Robichaud, P.R.; Cannon, S.H.; Martin, D.A. Current research issues related to post-wildfire runoff and erosion processes. Earth Sci. Rev. 2013, 122, 10-37. [CrossRef]

41. Campbell, G.S.; Jungbauer Jr, J.D.; Bristow, K.L.; Hungerford, R.D. Soil temperature and water content beneath a surface fire. Soil Sci. 1995, 159, 363-374. [CrossRef]

42. Badía, D.; Martí, C. Plant ash and heat intensity effects on chemicaland physical properties of two contrasting soils. Arid Land Res. Manag. 2003, 17, 23-41. [CrossRef]

43. Cawson, J.G.; Sheridan, G.J.; Smith, H.G.; Lane, P.N.J. Surface runoff and erosion after prescribed burning and the effect of different fire regimes in forests and shrublands: A review. Int. J. Wildland Fire 2012, 21, 857-872. [CrossRef]

44. Cawson, J.G.; Nyman, P.; Smith, H.G.; Lane, P.N.J.; Sheridan, G.J. How soil temperatures during prescribed burning affect soil water repellency, infiltration and erosion. Geoderma 2016, 278, 12-22. [CrossRef]

45. Badía, D.; López-García, S.; Martí, C.; Ortíz-Perpiñá, O.; Girona-García, A.; Casanova-Gascón, J. Burn effects on soil properties associated to heat transfer under contrasting moisture content. Sci. Total Environ. 2017, 601, 1119-1128. [CrossRef]

46. DeBano, L.F.; Krammes, J.S. Water Repellent Soils and Their Relation to Wildfire Temperatures. Hydrol. Sci. J. 1966, 11, 14-19. [CrossRef]

47. Hewlett, J.D.; Lull, H.W.; Reinhart, K.G. In defense of experimental watersheds. Water Resour. Res. 1969, 5, 306-316. [CrossRef]

48. Tetzlaff, D.; Carey, S.K.; Mcnamara, J.P.; Laudon, H.; Soulsby, C. The essential value of long-term experimental data for hydrology and water management. Water Resour. Res. 2017, 53, 2598-2604. [CrossRef] 
49. Latron, J.; Lana-Renault, N. The relevance of hydrological research in small catchments-A perspective from long-term monitoring sites in Europe. Cuad. Investig. Geogr. 2018, 44, 387-395. [CrossRef]

50. Isla, N.M.; Lee, J.L. Climate of San Diego, California. 2006. Available online: https://repository.library.noaa. gov/view/noaa/14098 (accessed on 21 December 2019).

51. Mathews, L. Vegetation and Fluvial Geomorphology Dynamics after Fire in Urban Mediterranean Riparian Areas. Master's Thesis, San Diego State University, San Diego, CA, USA, 2020.

52. Natural Resources Conservation Service. Web Soil Survey. Available online: https://websoilsurvey.sc.egov. usda.gov/ (accessed on 11 January 2020).

53. SanGIS. Sewer_Main_SD. Available online: http://www.sangis.org/download/index.html (accessed on 13 January 2020).

54. Campbell Scientific. Hydrosense II User Guide. Available online: http://s.campbellsci.com/documents/au/ manuals/au_hydrosense_ii_user_guide_10-11.pdf (accessed on 15 January 2020).

55. Meter Group Inc., USA. Mini Disk Infiltrometer. Available online: https://www.metergroup.com/environment/ products/mini-disk-infiltrometer/ (accessed on 15 January 2020).

56. Radinja, M.; Vidmar, I.; Atanasova, N.; Mikoš, M.; Šraj, M. Determination of Spatial and Temporal Variability of Soil Hydraulic Conductivity for Urban Runoff Modelling. Water 2019, 11, 941. [CrossRef]

57. Horel, J.; Splitt, M.; Dunn, L.; Pechmann, J.; White, B.; Ciliberti, C.; Lazarus, S.; Slemmer, J.; Zaff, D.; Burks, J. Mesowest: Cooperative mesonets in the western united states. Bull. Am. Meteorol. Soc. 2002, 83, 211-226. [CrossRef]

58. Scott, R.L.; Shuttleworth, W.J.; Keefer, T.O.; Warrick, A.W. Modeling multiyear observations of soil moisture recharge in the semiarid American Southwest. Water Resour. Res. 2000, 36, 2233-2247. [CrossRef]

59. Zhu, X.; He, Z.-B.; Du, J.; Chen, L.-F.; Lin, P.-F.; Li, J. Temporal variability in soil moisture after thinning in semi-arid Picea crassifolia plantations in northwestern China. For. Ecol. Manag. 2017, 401, 273-285. [CrossRef]

60. Brocca, L.; Ciabatta, L.; Massari, C.; Camici, S.; Tarpanelli, A. Soil Moisture for Hydrological Applications: Open Questions and New Opportunities. Water 2017, 9, 140. [CrossRef]

61. Mittelbach, H.; Seneviratne, S. A new perspective on the spatio-temporal variability of soil moisture: Temporal dynamics versus time-invariant contributions. Hydrol. Earth Syst. Sci. 2012, 16, 2169-2179. [CrossRef]

62. Brocca, L.; Zucco, G.; Mittelbach, H.; Moramarco, T.; Seneviratne, S.I. Absolute versus temporal anomaly and percent of saturation soil moisture spatial variability for six networks worldwide. Water Resour. Res. 2014, 50, 5560-5576. [CrossRef]

63. Hu, W.; Si, B.C. Estimating spatially distributed soil water content at small watershed scales based on decomposition of temporal anomaly and time stability analysis. Hydrol. Earth Syst. Sci. 2016, 20, 571-587. [CrossRef]

64. Ng, E.; Miller, P.C. Soil Moisture Relations in the Southern California Chaparral. Ecology 1980, 61, $98-107$. [CrossRef]

65. Margulis, S. Introduction to Hydrology. 2014. Available online: https://margulis-group.github.io/teaching/ (accessed on 29 March 2020).

66. Gomez-Plaza, A.; Martinez-Mena, M.; Albaladejo, J.; Castillo, V.M. Factors regulating spatial distribution of soil water content in small semiarid catchments. J. Hydrol. 2001, 253, 211-226. [CrossRef]

67. Debano, L. The role of fire and soil heating on water repellency in wildland environments: A review. J. Hydrol. 2000, 231, 195-206. [CrossRef]

68. Rutsch, M.; Rieckermann, J.; Cullmann, J.; Ellis, J.B.; Vollertsen, J.; Krebs, P. Towards a better understanding of sewer exfiltration. Water Res. 2008, 42, 2385-2394. [CrossRef] [PubMed]

69. Rueedi, J.; Cronin, A.A.; Morris, B.L. Estimation of sewer leakage to urban groundwater using depth-specific hydrochemistry. Water Environ. J. 2009, 23, 134-144. [CrossRef]

70. Divers, M.T.; Elliott, E.M.; Bain, D.J. Constraining nitrogen inputs to urban streams from leaking sewers using inverse modeling: Implications for dissolved inorganic nitrogen (DIN) retention in urban environments. Environ. Sci. Technol. 2013, 47, 1816-1823. [CrossRef] [PubMed]

71. Jones, A.; Brunsell, N. A scaling analysis of soil moisture-precipitation interactions in a regional climate model. Theor. Appl. Clim. 2009, 98, 221-235. [CrossRef] 
72. Cai, Y.; Zheng, W.; Zhang, X.; Zhangzhong, L.; Xue, X. Research on soil moisture prediction model based on deep learning. PLoS ONE 2019, 14, e0214508. [CrossRef]

73. Crow, W.T.; Chen, F.; Reichle, R.H.; Xia, Y.; Liu, Q. Exploiting Soil Moisture, Precipitation, and Streamflow Observations to Evaluate Soil Moisture/Runoff Coupling in Land Surface Models. Geophys. Res. Lett. 2018, 45, 4869-4878. [CrossRef] [PubMed]

74. Witthoeft Alan, F.; Conkle Christopher, S.; Stern, A. Techniques for In Situ Evaluation of Stormwater Infiltration Rate. In Geo-Congress 2014 Technical Papers: Geo-Characterization and Modeling for Sustainability; American Society of Civil Engineers: Reston, VA, USA, 2014; pp. 3432-3443. [CrossRef]

75. Wang, P.; Zheng, H.; Ren, Z.; Zhang, D.; Zhai, C.; Mao, Z.; Tang, Z.; He, X. Effects of Urbanization, Soil Property and Vegetation Configuration on Soil Infiltration of Urban Forest in Changchun, Northeast China. Chin. Geogr. Sci. 2018, 28, 482-494. [CrossRef]

76. Robichaud, P.R. New Procedure for Sampling Infiltration to Assess Post-Fire Soil Water Repellency; Research note RMRS; RN-33; US Dept of Agriculture, Forest Service, Rocky Mountain Research Station: Fort Collins, CO, USA, 2008.

77. Ebel, B.A.; Moody, J.A. Synthesis of soil-hydraulic properties and infiltration timescales in wildfire-affected soils. Hydrol. Process. 2017, 31, 324-340. [CrossRef]

78. Moody, J.A.; Martin, R.G.; Ebel, B.A. Sources of inherent infiltration variability in postwildfire soils. Hydrol. Process. 2019, 33, 3010-3029. [CrossRef]

79. Bouma, J.; Belmans, C.F.M.; Dekker, L.W. Water Infiltration and Redistribution in a Silt Loam Subsoil with Vertical Worm Channels. Soil Sci. Soc. Am. J. 1982, 46, 917-921. [CrossRef]

80. Bradford, J.M.; Ferris, J.E.; Remley, P.A. Interrill Soil Erosion Processes: I. Effect of Surface Sealing on Infiltration, Runoff, and Soil Splash Detachment. Soil Sci. Soc. Am. J. 1987, 51, 1566-1571. [CrossRef]

81. Dunne, T.; Zhang, W.; Aubry, B.F. Effects of Rainfall, Vegetation, and Microtopography on Infiltration and Runoff. Water Resour. Res. 1991, 27, 2271-2285. [CrossRef]

82. Cerdà, A. Seasonal changes of the infiltration rates in a Mediterranean scrubland on limestone. J. Hydrol. 1997, 198, 209-225. [CrossRef]

83. Robichaud, P.R. Fire effects on infiltration rates after prescribed fire in Northern Rocky Mountain forests, USA. J. Hydrol. 2000, 231, 220-229. [CrossRef]

(C) 2020 by the authors. Licensee MDPI, Basel, Switzerland. This article is an open access article distributed under the terms and conditions of the Creative Commons Attribution (CC BY) license (http://creativecommons.org/licenses/by/4.0/). 